\title{
FROM SIMPLE TO COMPLEX CONFIGURATION: SUSTAINABILITY OF GESTALT PRINCIPLES OF VISUAL PERCEPTION WITHIN THE COMPLEXITY PARADIGM
}

\author{
Zeynep MENNAN
}

\section{Received: 30.09 .2009}

Keywords: Gestalt; perception; prägnanz; closure; simplification; complexity.

1. The design research conducted at $C^{0} D^{e} R e$ in 2005 and 2006 has been first presented at the Architectural Education Forum 3 as part of an educational experiment questioning the visual training in architectural education (Mennan, 2006) and at the 15th Scientific Convention of the International Society for Gestalt Theory and its Applications (Mennan, 2007), which has provided for a broader envisioning of the experiment within the larger context of perception in the field of psychology. Both conferences have provided for the development of the contents of this paper.

2. Arch 719 (585) Computational Design Research Lab, METU, Department of Architecture, Ankara, Turkey. Critics Spring 2006: Assoc. Prof. Dr. Zeynep Mennan, Asst. Prof. Dr. Mine Özkâr, Res. Asst. Başak Uçar. Students: Miray Baş, Elif Ensari, Eser Ergün, Betül Koç, Meltem Mimarsinanoğlu, Işıl Ruhi. Critics Spring 2007: Assoc. Prof. Dr. Zeynep Mennan, Res. Asst. Başak Uçar, Res. Asst. Gökhan Kınayoğlu. Students: Aslı Arpak, Ziya İmren, Erkmen Korkmaz, Mehmet Yasavul. I would like to express my sincere gratitude and thanks to the instructors and students who have shared this experience, enriched with their creative contributions.
The paper presents a design research project developed in 2006 and in 2007 at the Computational Design Research Lab (CoDeReL)(1). CoDeReL is an elective graduate design research studio initiated in 2005 at the Middle East Technical University, Department of Architecture (2), to function as an integrated research and teaching structure. The double educational and research agenda of the studio aims at enhancing intellectual infrastructure for research and design in the architecture/technology interface and adresses various issues and problematics detected in the field of computational design research. One of the main objectives of the studio is to position computational design research in its current theoretical and epistemic context and to develop a consciousness of historical continuity within the disciplinary field of architecture. To this aim, design experiments at CoDeReL attempt to draw together contemporary and historical problem situations for the production of new and creative linkages fostering new knowledges and understandings of architectural evolution.

The design research presented here is an attempt to re-contextualize and re-problematize the premises of the Gestalt theory of visual perception in the context of complex and unstable forms that now populate a new formal and plastic catalogue. Increasingly predictive and accurate formalist procedures set forth by diverse morphological theories in the rationalization of complex form seem unable to remedy for the challenge these forms pose to the limits of spontaneous intuition and visual perception. This challenge that would require a sharpening and augmentation of intuitionist and perceptual abilities in the apprehension of complex form is a rarely adressed problem in recent formal research. The absence of a new theory of visual perception brings to the fore a long trusted resource in the field; the gestalt principles of visual perception. These basic principles now call for a reconsideration as they are confronting challenges posed by geometric and conceptual developments in the complexity paradigm, and that need to be adressed in terms of the 
3. The research follows a strong faculty tradition of referencing Gestalt rules in design education since the early 1960s. See Denel (1979) and Günay (2007) ways in which they might affect visual perception. The research agenda of the studio in Spring 2006 and 2007 is set to test the Gestalt principles of visual perception in various design exercises experimenting with the sustainability of Gestalt principles (3). These exercises proceed along a simplicity-complexity axis on which it is attempted to define a conceptual and geometric threshold beyond which the Gestalt laws of perceptual organization would become problematic.

\section{GESTALT THEORY OF VISUAL PERCEPTION}

Developed in early 20th century, Gestalt theory adopts a holistic and non-additivist approach to the study of objects of perception, perceived as organised and structured wholes rather than the sum of their parts, leading to the foundational gestalt statement that 'the whole is different than the sum of the parts' (Koffka,1935). The present study's reference to Gestalt theory is limited to the investigations on visual perception by the Berlin school of Gestalt theory founded by Wertheimer, Köhler and Koffka. The theoretical and historical re-contextualization of the claims of the Berlin school in the context of complexity departs from an interrogation of the seminal presupposition of Gestalt theory, that is, its claim of the simplifying and unifying tendency of the perceiving mind which reduces phenomenological complexity into a latent, simple and regular order in the visual reconstruction of forms. This self-organising tendency towards simplification and unification is formulated in Wertheimer's "Laws of Organization in Perceptual Forms" (1923/1938). Gestalt theory's specific concern with the perception of visual forms is mainly indebted to this article, also known as "the dot essay" because of its illustrations in constellations of dots (Behrens, 2004), in which Wertheimer formulated figurative, positional and qualitative gestalt principles grounded on the holistic understanding of the relationship between the parts and the whole of visual experience. To recall briefly, these principles are:

Factor of Proximity; a positional concern about the respective location of the objects of perception, stating about the visual unity created by objects that come closer to each other.

Factor of Similarity; a figurative concern about the effect on perception of the degree of sameness between various objects, stating that the human mind tends to group together similar objects.

Factor of Uniform Destiny (or "Common Fate") stating that a slight change of direction would not affect the grouping of objects perceived together.

Factor of Objective Set (Einstellung); stating that a particular organization is the result of the sequence in which it appears. Wertheimer uses this case to assert that seeing one organization instead of another is a result of objective conditions.

Factor of Direction or Continuance is another positional factor in the visual grouping of objects that have the same directionality.

Factor of Closure is a basic qualitative gestalt principle about the completion or closure in the mind of visually incomplete images. The closure principle grounds upon all previous principles and expresses the gestalt tendency towards unification and wholeness. The closure principle is also closely related to the issue of gestalt simplification for it may work through the addition of missing parts, as well as the elimination of 
redundant ones, a choice that seems to depend on the degree of simplicity or complexity of the image.

Figure-Field denotes the tendency of the mind to identify a figure from its background or field. When the figure-field relationship is rendered ambiguous by a perfect balance between the figure and its ground, perception tends to favor one interpretation over the other, a phenomenon also known as a 'gestalt switch'.

These principles of visual organization do not work in isolation but coexist in most figures, strengthening their mutual and overall effects. They further suggest that the holistic reconstruction of forms operates through universal principles that are innate and universal rather than learned.

\section{GESTALT PREFERENCE FOR UNITY AND SIMPLIFICATION: THE LAW OF PRÄGNANZ OR THE MINIMUM PRINCIPLE}

All the factors developed by Wertheimer contribute to the main problematic of Gestalt theory, that of unification and simplification, and to the overarching gestalt principle that the mind privileges the simplest and most stable visual reconstruction. This principle, developing into the law of Prägnanz, accounts for selection among various perceptual experiences to which an initial stimulus can give rise, in favor of the most simple and stable figure, which also corresponds to the concept of 'Good Form' (Gute Form) or 'Good Gestalt' (Wertheimer, 1923/1938).

Luccio (1999a) notes that Prägnanz is "definitely a cardinal concept in Gestalt theory", but also a problematic one because of the ambiguities in its definition: "The Gestaltists have often been criticised for having turned Prägnanz into a key to open all doors, without ever having given it a strict definition" (Luccio, 1999a, 91). The concept is introduced by Wertheimer in his first major theoretical work, "Über das Denken der Naturvölker" (On the Thinking of Indigenous People), a paper which appeared in Zeitschrift für Psychologie in 1911, shortly preceding the 1912 paper on motion, "Experimentelle Studien über das Sehen von Bewegung" (Experimental Studies of the Perception of Motion)(4) considered as Wertheimer's seminal work (Luccio, 1999a). But Wertheimer talks about the law of prägnanz only two years later in 1914 at the VI Congress of Experimental Psychology in Göttingen (Luccio, 1999b). In the 1923 dot essay, the concept appears again where Wertheimer speaks of Prägnanzstufen (areas of prägnanz). Luccio, discusses the ambiguity of the concept by distinguishing two definitions given by Wertheimer which are however often assumed to be intermingled:

"Prägnanz is a "quality possessed by certain specific objects, forms or events belonging to our immediate perceptual experience which makes them "unique", "singular", "privileged". All the shapes which are phenomenally singular or "privileged" are "Good Gestalten": It is the case of the equilateral triangle, of the circle, of the square, of the sinusoid, etc. In this sense, "prägnant" indicates phenomenal structures which are "regular"; they are endowed with internal coherence;... But Wertheimer also gave a second sense of Prägnanz, that of the lawfulness of the process leading to the formation of visual objects. According to this second meaning, the term is used by Wertheimer to indicate the fact that it is rather a "meaningful" process. The principle of organization acts as precise laws to which the process is forced to obey, overall in the sense of maximum economy and simplicity. Its result is a perfect balance of the forces at play and thus has also a maximum of stability and resistance to change" (Luccio, 1999a, 91, emphasis by the author). 
Figure 1. Ergun E.(2006) Prägnanz Test I/Design exercise 2: Regularity/Irregularity, $\mathrm{C}^{\mathrm{D}} \mathrm{D}^{\mathrm{e}} \mathrm{R}$ L.
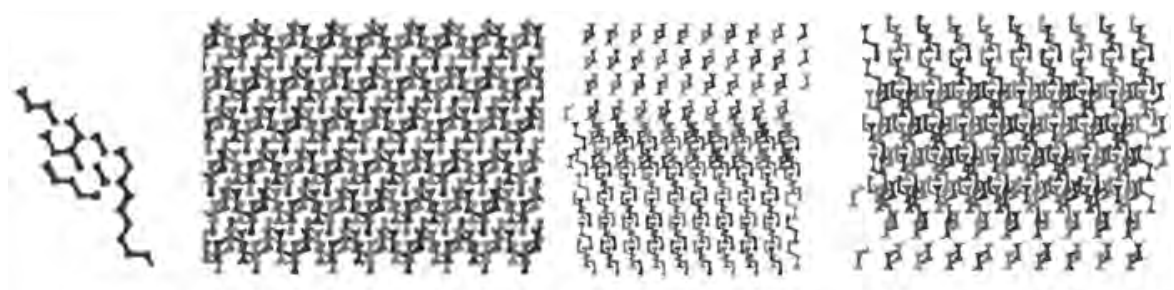

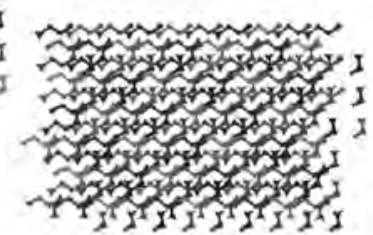

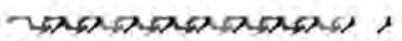

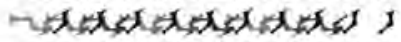

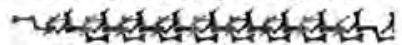

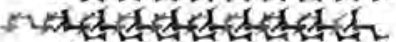

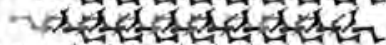

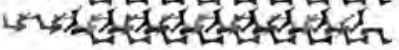

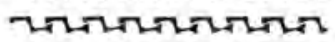

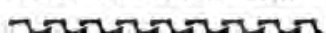

The second meaning of the law of prägnanz as the law of maximum economy and simplicity is reinforced in Koffka's 'principle of minimum and maximum simplicity': "Roughly speaking, a minimum simplicity will be the simplicity of uniformity, a maximum simplicity, that of perfect articulation" $(1935,171)$. Koffka retains the two meanings of prägnanz as (a) "figural goodness" and as (b) perceptual economy while acknowledging the limits and the vagueness of the concept as defined by Wertheimer (5).

The studio experiment started with testing the law of prägnanz in the derivation and transformation of forms and patterns in low orders of complexity that would correspond to Koffka's scale of minimum to maximum simplicity. Design exercise 1 and Prägnanz Test I / Design exercise 2: Regularity / Irregularity have dealt with simple and uniform 2D geometric figures multiplied through operations such as symmetry, rotation, translation and reflection. The aim of the experiment was to observe the formation of strong gestalts on the basis of regularity and formal stability in the higher level configurations obtained (Figure 1).

This first test has shown that the principle of prägnanz can be observed to be fully operative in the case of a geometric foundationalism. Indeed, the ambiguous concept of 'figural goodness' expressed by gestaltists extends the connotations of the initially perceptual principle of prägnanz into implicit and equally ambiguous moral/aesthetic claims that are known to have accounted for the modernist preference for formal simplicity and abstraction. Evaluating Gestalt theory and its architectural, formal and geometric implications and contributions in its own historical context, the Bauhaus can be said to offer an accurate instance of the intermingling of the two connotations of prägnanz, that can be phrased as the favoring of all stable percepts as "good gestalts". Roy Behrens, in his article "Art, Design and Gestalt Theory" (2004) notes the appeal of Gestalt theory to artists and teachers of the Bauhaus, including Paul Klee, Wassily Kandinsky and Josef Albers, who had known about Wertheimer's work and had attended lectures by gestalt psychologists at the Bauhaus. Behrens refers to Teuber's work to affirm that Klee was one of the few artists directly aware of Wertheimer's laws of perceptual organization, using some of its diagrams in his paintings in the 1930's (6). This interest has further been mutual, as testified by the article in Die Weltbühne on honesty and clarity in building design, published by the gestalt psychologist Rudolf Arnheim in 1927, shortly after his visit to Bauhaus Dessau (Behrens, 2008)(7). Similarly, Crétien van Campen, in his article "Early Abstract Art and Experimental 
8. Indeed, the birth of Gestalt theory is attributed to an earlier paper by Christian von Ehrenfels ("On 'Gestalt Qualities'”) published in 1890. This initial discussion of the genesis of a gestalt quality has given rise to two schools of psychology, opposing the idealism of the Graz school (Ehrenfels, Benussi, Meinong) to the realism of the Berlin school (Stumpf, Wertheimer, Koffka, Kohler)(Smith, 1994).
Gestalt Psychology" remarks parallelisms between Kandinsky's thinking and Wertheimer's Gestalt theory (1997, 134f). Van Campen even suggests that Kandinsky may be considered a predecessor of the Gestalt approach to perception since the manuscript of Kandinsky's Point and Line to Plane had been written in 1911, hence preceding the publication of Wertheimer's first article on gestalt phenomena in 1912 (1997, 135)(8). Publications such as Language of Vision (1944) by Gyorgy Kepes, using illustrations by Wertheimer, Koffka and Kohler, and Art and Visual Perception: A Psychology of the Creative Eye (1954) by the Berlin gestaltist Rudolf Arnheim have provided for a scientific validation of Gestalt theory in art and design education (Graham, 2008; Behrens, 2004). Evaluating the publications of the Bauhaus teachers as "primers for the grammar of visual writing", Lupton notes that "Gestalt psychology has since become a dominant theoretical source for basic design teaching" (1991, 22).

The modernist preference for geometric simplicity seems to be closely related with the recuperation of the gestalt issue of simplification that has led eventually into the development and dissemination of an aesthetic style: "Inadvertently, due to its emphasis on flat abstract patterns, structural economy and implicitness, gestalt theory became associated with the modernist tendency toward "aestheticism", the belief that -like music and architecture- all art is essentially abstract design..." (Behrens, 2004). The Bauhaus conception of visual form has found a strong backup in Gestalt theory's claim of the universality of perceptual principles, legitimized as a style. Lupton notes that "part of the Bauhaus legacy is the attempt to identify a language of vision, a code of abstract forms adressed to immediate biological perception rather than to the culturally conditioned intellect" (Lupton, 1991, 22). What happens then when this allegedly innate tendency for simplification meets the new cultural tendency for complexification? Admitting that the success of gestalt principles is related with formal simplicity, clarity and stability, as stated in the law of prägnanz, it seems pertinent to question the challenges and limits presented by the complexity paradigm to the gestalt preference for simplification.

\section{GESTALT THEORY AND COMPLEXITY}

Investigations of Gestalt psychology during the 20th century focussed on reducing phenomenological complexity by developing a system of perceptual organization claiming universal perceptual capabilities for coping with the complexity of the visual world. The present complexity paradigm on the other hand, reverses the task: advances in complexity sciences together with improved tools and technologies used in morphogenetic and computational research contribute to the generation of ever more complex forms, hence creating, sustaining and promoting complexity. A major shift can be detected here that brings forth a complete change of environment, presenting important implications at perceptual and aesthetic levels. Mario Carpo (2004) calls this "a new visual universe" characterized by a population of "changing, morphing, imprecise or incomplete images". Such images present a challenge to almost all gestalt principles of visual perception but in particular to the principle of closure. The closure phenomenon is an essential prerequisite of the law of prägnanz and of the tendency towards simplification since the human mind proceeds to closure when it exceeds the limit of the complexity of information present in visual experience. The mind then simplifies the image by closing it and retaining only the essential parts. Incompleteness and continous morphing in a visual image hence resist closure and produce perceptual 
discomfort. But they also jeopardize the visual field's tendency to behave as a whole. The whole is the prerogative of a 'good gestalt' and the desired simplification is reached through operations of prägnanz and closure that are tendencies striving to make the whole salient. Where the visual image can not behave as a whole, that is, where a complexity threshold is reached beyond which the whole becomes difficult to observe, the visual whole's tendency to maintain itself at its simplest state is challenged. It seems then that the whole needs to be 'bounded' in order to be recognizable as a discrete and closed geometric entity, though never stated as such in Gestalt theory but implicit in its emphasis on figure-ground segregation and recognizable contour line. This notion of a 'bounded whole' is an indication that gestalt principles may be subject to geometric constraints, that is, they may be operative only in certain particular geometries, namely discrete geometries, where the closure of a figure occurs within the field of human vision.

Bernard Cache (1998), in his "Plea for Euclid", notes that "Euclid's work...is a description of space both as a form of intuition and physical phenomena" and argues that "as regards multidimensional phenomena, insofar as we want to give an easy intuition of them, the best geometric vehicle remains 3D Euclidean space". The geometrical world of Gestalt theory is one of Euclidian intuition: Gestalt theory has been historically operative within the Euclidian geometry of inertia, on the assumption of stable, indeformable form. The first group of exercises have tested Wertheimer's principles of visual organisation in a discrete, "metric geometry", using transformations that define a "group of movements which transform geometrical figures without affecting distances nor angles in these figures" (Cache, 1998). Moving from metric geometry towards topology, the same principles have been tested again by applying a form a group of topological transformations, such as folding, streching, twisting, curving/ bending, shrinking, expanding, etc., to morph the form towards its limit of formlessness.

Prägnanz Test IIa/Design Exercise 3a: Closure/Formlessness; this topological exercise has been seen to problematize the "factor of similarity", or isomorphism, reformulated as a homeomorphism in topological terminology, that is, a special kind of isomorphism disinterested in similarity of shape or structure. While the application of homeomorphisms do not affect the topological properties of objects, the topological focus on relations may radically change their figurative properties (Figure 2). The visual organisation of topologically self-differentiating forms renders the figurative gestalt principle of 'similarity' either redundant or non-applicable. On the other hand, the positional principles of 'common fate' and of 'continuance' are reinforced. But topological operations mainly affect the qualitative principles of closure and prägnanz, by a relentless morphing that inhibits the stabilization of the figure. The logic of variation of these complex forms resists any revendication of hierarchy between different formal states, hence putting the principles of closure and Prägnanz to test. A complex form resists its closure in the same manner as simpler forms; complex forms surpass perceptual capacities and therefore defer closure. When the visual image is simple, the entire gestalt can be perceived in one single intuitive glance. When the image is complex, the perceptual processing of the visual experience is dealt with in Gestalt theory through a continous subdivision of the complex whole into parts that can end up becoming sub-wholes in themselves. Part of the whole conceived can then become a gestalt in its own right. In the case of 
Figure 2. Koç, B. (2006) Homeomorphisms, $\mathrm{C}^{\circ} \mathrm{D}^{e} \mathrm{R}$ L.

Figure 3. 'Gestalt Scoring Sheet' (2006), $C^{\circ} D^{e} R^{e} L$.

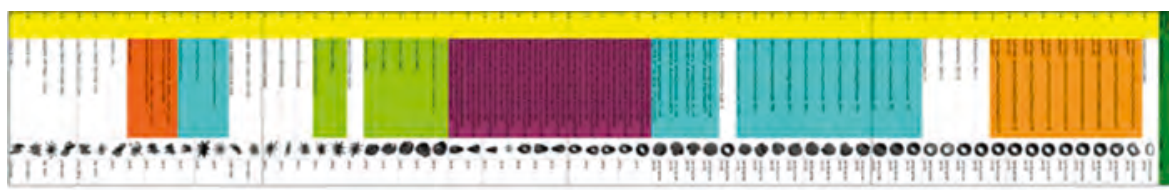

0000000000 000000000000000

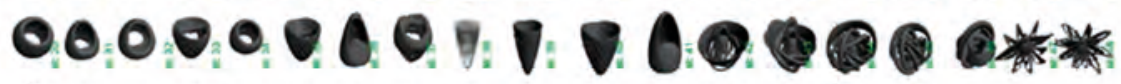

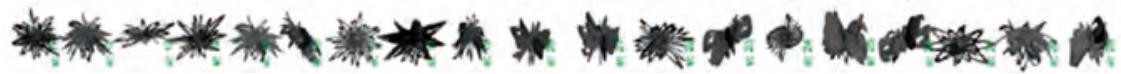

\begin{tabular}{|c|c|c|c|c|c|c|c|c|c|c|c|c|}
\hline \multicolumn{6}{|l|}{ PTX de $x x$} & \multicolumn{7}{|c|}{ Gestalt Scoring Sheet $C^{\circ} D^{e} R^{e} L$} \\
\hline Date & \multicolumn{11}{|c|}{ Time to Complete } & \multirow{3}{*}{ 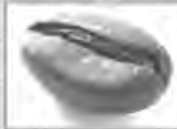 } \\
\hline \multicolumn{12}{|l|}{ FILE NAME } & \\
\hline \multicolumn{12}{|c|}{ EXPERIMENTER NAME } & \\
\hline & & 0 & 1 & 2 & 3 & 4 & 5 & 6 & 7 & 8 & 9 & \multirow[b]{2}{*}{ open/formless } \\
\hline Closure & $\begin{array}{l}\text { closed / identifiable } \\
\text { configuration }\end{array}$ & & & & & & & & & & & \\
\hline Part-whole & figure/ground & & & & & & & & & & & figure/field \\
\hline Intricacy & smooth/bold & & & & & & & & & & & $\begin{array}{l}\text { striated/ } \\
\text { involuted }\end{array}$ \\
\hline Complexity & simple & & & & & & & & & & & complex \\
\hline Prägnanz & $\begin{array}{l}\text { strong gestalt/ 'good } \\
\text { form' }\end{array}$ & & & & & & & & & & & $\begin{array}{l}\text { weak gestalt/ } \\
\text { collapse }\end{array}$ \\
\hline Whole & bounded & & & & & & & & & & & unbounded \\
\hline $\begin{array}{l}\text { Gestalt } \\
\text { collapse }\end{array}$ & reversible & & & & & & & & & & & irreversible \\
\hline
\end{tabular}

complex figures, we may advance the idea of a 'serial gestalt' where parts are continously bound to ever larger wholes, with sub- wholes acting as parts of more complex wholes. However issues of closure, prägnanz and simplification can be expected to become problematic if these subwholes continously inflect towards an unbounded and unspecified whole (Mennan, 2003). Prägnanz Test II has been designed to question the validity of the minimum principle and the operative limits of the principles of closure and prägnanz in the context of unbounded wholes. Students have been required to document every step and fill a corresponding 'Gestalt Scoring Sheet', inspired from the "Bender Visual Motor Gestalt Test" developed by the Gestalt psychologist Lauretta Bender in 1938 (Figure 3). The 'Gestalt Scoring Sheet' provided for an evaluation of existing and up-dated gestalt principles on a scale of 0 to 9 for each object of perception developed in the studio. The term 'gestalt colllapse' has been introduced to denote limit cases where gestalt principles fail and that have been asked to be detected. Scoring sheets have been filled both by students and the evaluating jury members. Evaluation hence proceeded from the immediacy of a first perception to a comparison and discussion of the scores given by different experimenters. 


\section{a. The Unbounded Whole: Blob and Field}

Self-differentiating figures opposing the gestalt requisites of completion and stability (closure and prägnanz) are known as blobs. The first part of Prägnanz Test II (Prägnanz Test IIa / Design Exercise 3a :Closure/Formlessness) adressed the issue of the unbounded whole with respect to the blob. Brian Massumi (1995) defines blobs as "active elements or "primitives" which combine to generate their own space"; this space is a field, that is, "an active space composed by forces of interaction between dynamic elements". This definition of field is quite different than the one evoked by Wertheimer (1938) in his discussion of the figure-field relationship, where he presupposes the existence of an inert field on which perception would occur by way of differentiation between the figure and its ground. Massumi's description of the field of the blob-space re-problematizes both the figure-field and the parts-whole relationship of a gestalt experience as described by Wertheimer:

The "whole" is not a whole at all, but an infolding-expressive field of variation. The self-activity and heterogeneity of this space is in stark contrast to the inertness and homogeneity of the Euclidean matrix... The forces of the blob space are endogenous; those of Euclidean space are exogenous (Massumi, 1995)(Figure 3a, 3b).
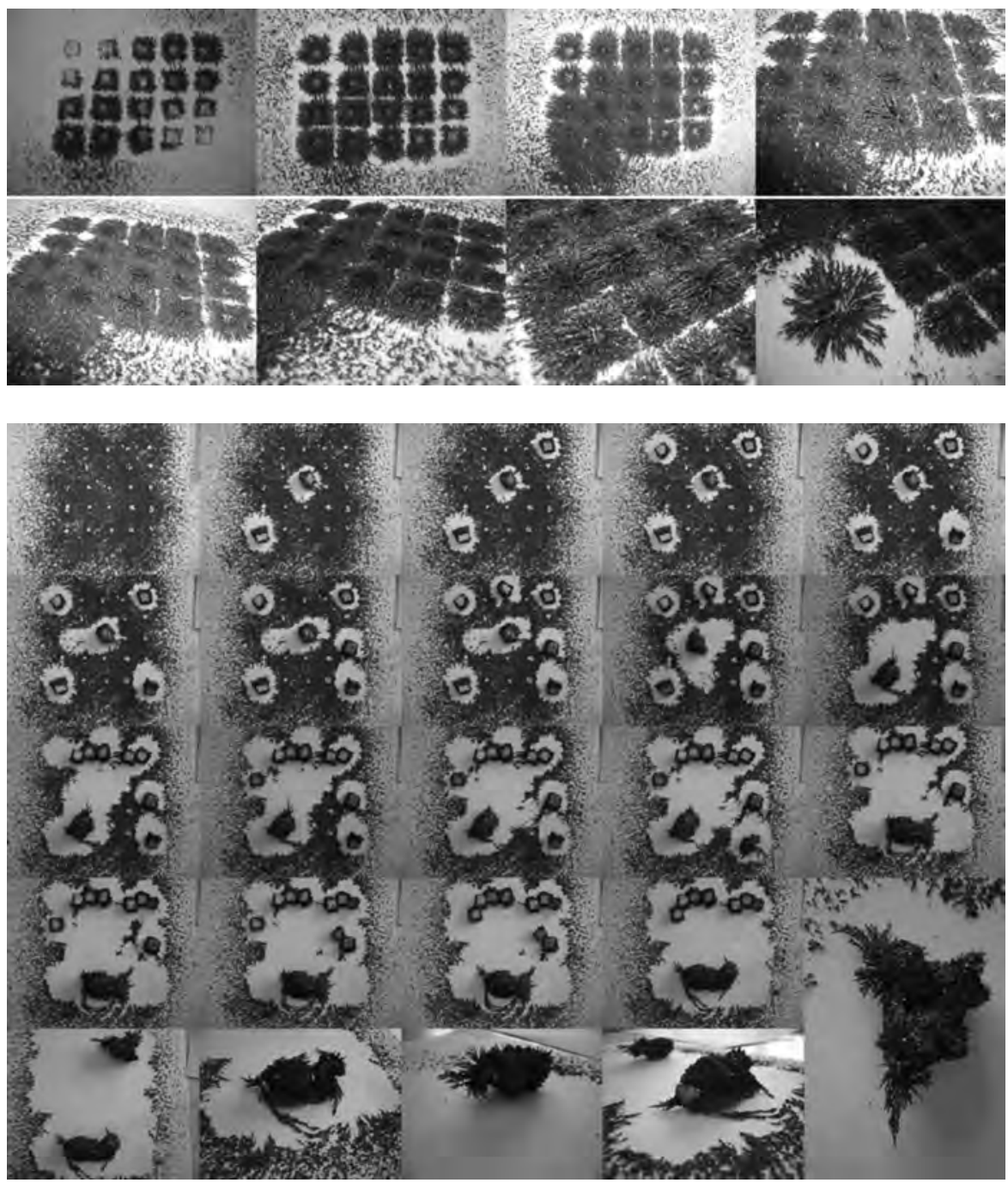


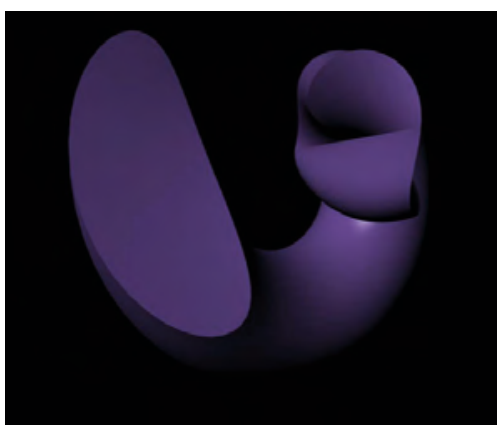

Figure 3c-e. Mimarsinanoğlu, M. (2006) Prägnanz Test IIa/Design Exercise 3a Closure/Formlessness, $\mathrm{C}^{\circ} \mathrm{D}^{\mathrm{e}} \mathrm{R}^{\mathrm{e}} \mathrm{L}$.

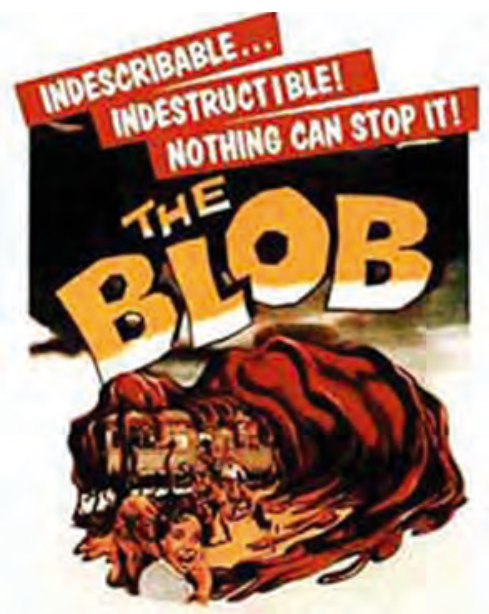

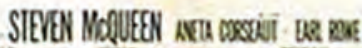

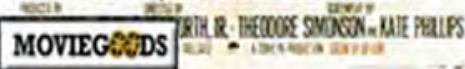

Figure 4. THE BLOB (1958/ Tonylyn Prod./ Paramount) 83 mins. Dir: Irwin S. Yeaworth Jnr. Retrieved from: IMP awards, 1958 Movie Poster Gallery: http: / / www.impawards. com/1958/std.html
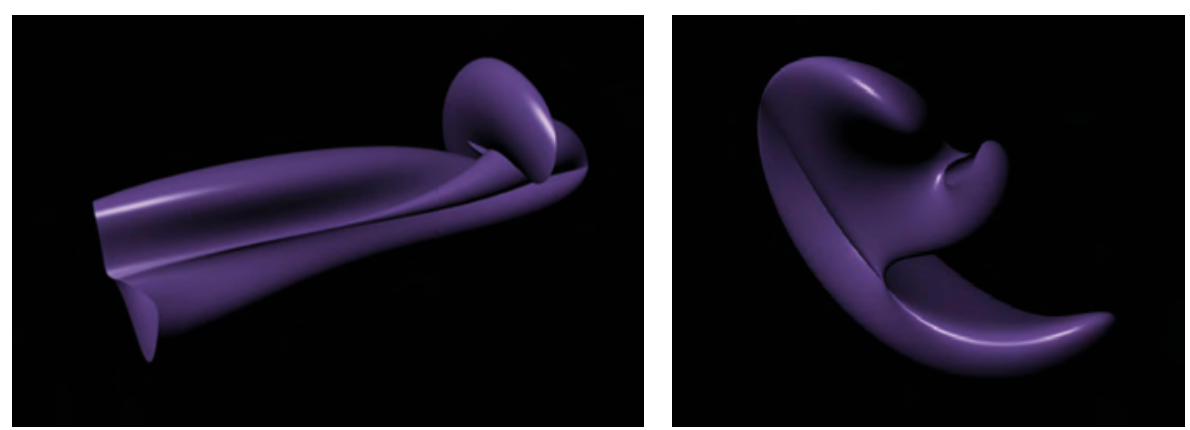

The blob maintains Gestalt theory's holistic claim of the inseparability of parts and whole; however the internal self-differentiation of the blob subverts the gestalt notion of the bounded whole towards an unbounded one. The blob presents a perfect instance of an unbounded whole: its formal indeterminacy resists closure and inhibits prägnanz, making impossible the selection and fixity of a 'good form', in other words, of a 'good blob' (Figure 3c-e). The fuzzy edge of the blob constantly delays the expectation of closure and figure singularity.

Indeed, the very notion of a blob defies that of a gestalt: Remembering the German meaning of gestalt as form or shape, the blob, denoting the formless, would be its perfect antonym. Thinking in terms of Gestalt psychology, the psychological counterpart of such a gestalt collapse would correspond to an experience of horror. A classic of horror movies, "The Blob" (1958) exploited the horrific consequences of an ever-growing unbounded whole, expressed as "Indescribable...Indestructible! Nothing can stop it !" in the movie poster (Figure 4).

\section{b. The Unbounded whole: Intricacy}

The second part of Prägnanz Test II (Prägnanz Test IIb / Design Exercise 3b : Closure/Compositional intricacy) focused on the concept of intricacy, again with respect to the issue of the unbounded whole, to test whether an ever increasing complexity and a constant deferral of closure invalidates or renders impossible the perceptual tendency towards simplification. The exhibition "Intricacy" (2003) at ICA, University of Pennsylvania, curated by Greg Lynn, re-defined and re-introduced the concept of intricacy within the discourse of complexity. Lynn (2003) declares that 'the primary characteristic unique to complexity is a divisional unification of disparate components without totality or wholes" and notes that "in an intricate network, there are no details per se. Detail is everywhere, ubiquitously distributed and continuously variegated in collaboration with formal and spatial effects...intricacy implies complexity all over without recourse to compositional contrast". This ubiquitous distribution of detail problematizes the parts-whole relationship of a visual experience: neither the whole, nor the parts can be identifiable in an intricate composition which claims for an excessive holism expressed in an increased connectionism. Intricacy defines an involution of parts and wholes, and appears as the conceptual counterpart of the blob, producing again an unbounded whole annihilating the principle of closure. An intricate composition is obtained after excessive repetition of a simple discrete recognizable module the order of which ends up overflowing the percept (Figure 5a, 5b, 6). 

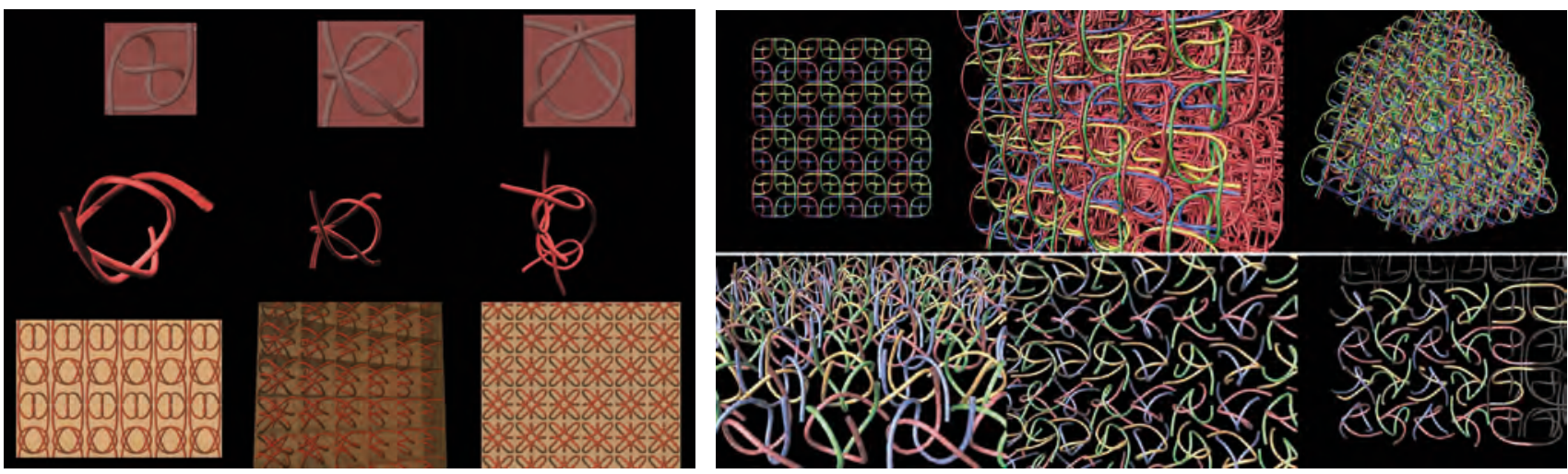

Figure 5a, 5b. Ensari, E. (2006) Prägnanz Test IIb; Design Exercise 3b:Closure/ Compositional intricacy, $\mathrm{C}^{0} \mathrm{D}^{e} \mathrm{R}^{\mathrm{e}} \mathrm{L}$

Figure 6. Mimarsinanoğlu, M. (2006) Prägnanz Test IIb; Design Exercise 3b: Closure/Compositional intricacy, $\mathrm{C}^{\circ} \mathrm{D}^{e} \mathrm{R}^{\mathrm{e}} \mathrm{L}$.

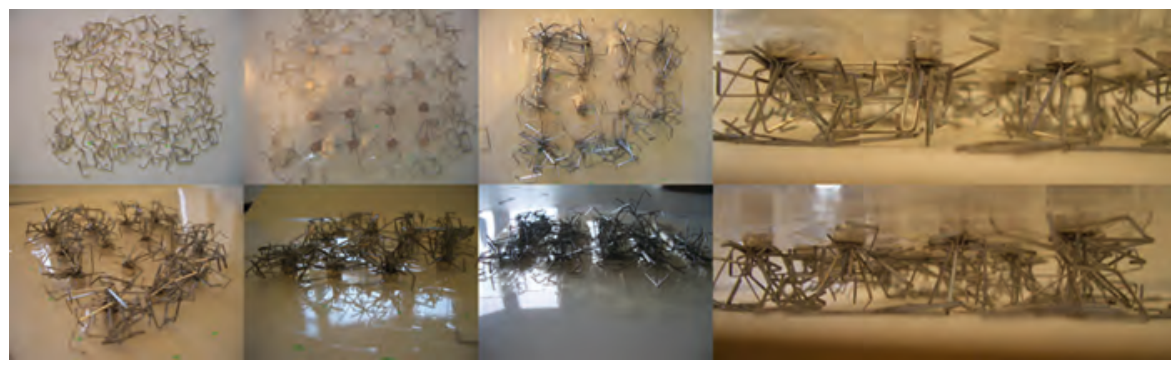

\section{c. The Blob-Intricacy Scale}

The last design experiment built upon the discussion of the former two concepts for the production of a Blob-Intricacy Scale. The design exercise consisted of considering a blob as a field and applying levels of disturbance and striations to its sub-fields. The forces (tension, compression, shrinkage, magnetic field, wearing, noise, transparency, reflection, etc.) applied to the initial blob (defined as $\mathrm{B}_{0} \mathrm{~F}_{0}$ : perfect smoothness) acted on overlapping
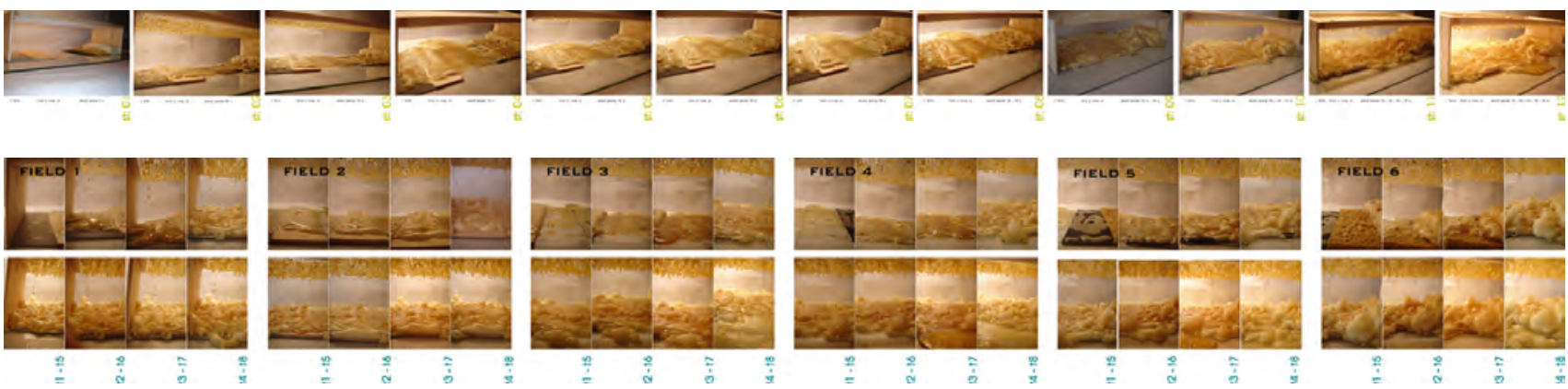

Figure 7a-d. Koc, B. and Mimarsinanoğlu, M. (2006) Blob-Intricacy Scale. Test 1/ Polyurethane foam, $\mathrm{C}^{\circ} \mathrm{D}^{\mathrm{e}} \mathrm{R}^{\mathrm{e}} \mathrm{L}$.
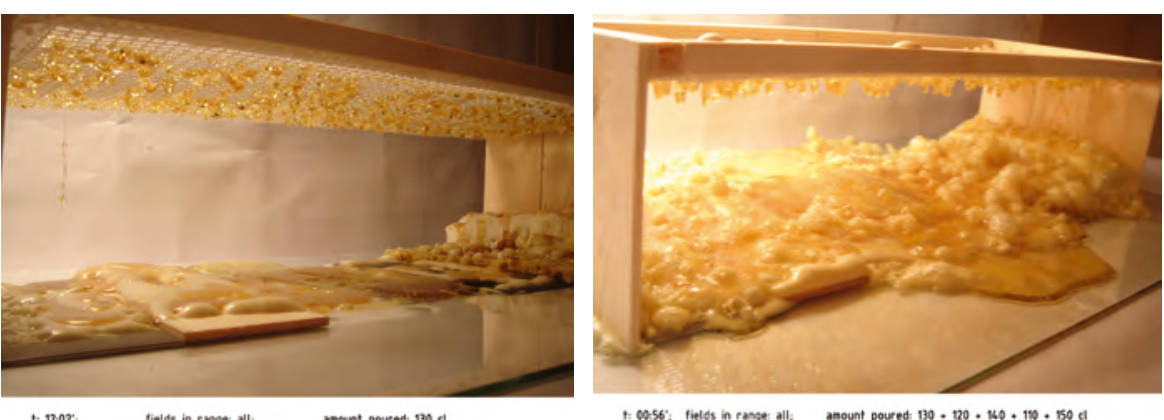

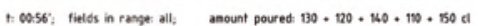




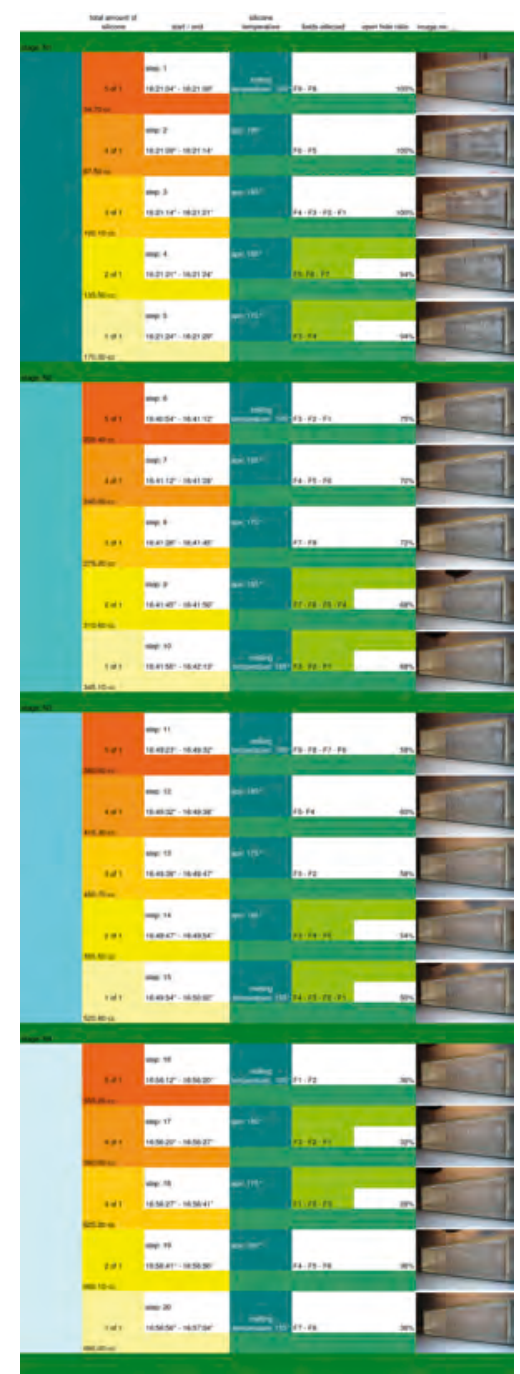

Figure 7e, 7f. Koç, B. and Mimarsinanoğlu, M. (2006) Blob-Intricacy Scale. Test 2/ Silicone, $C^{\circ} D^{e} R^{e} L$.
9. An instance of such quantitative models is the research conducted by Desolneux, Moisan and Morel on computational prägnanz: Moisan and Morel (2003).

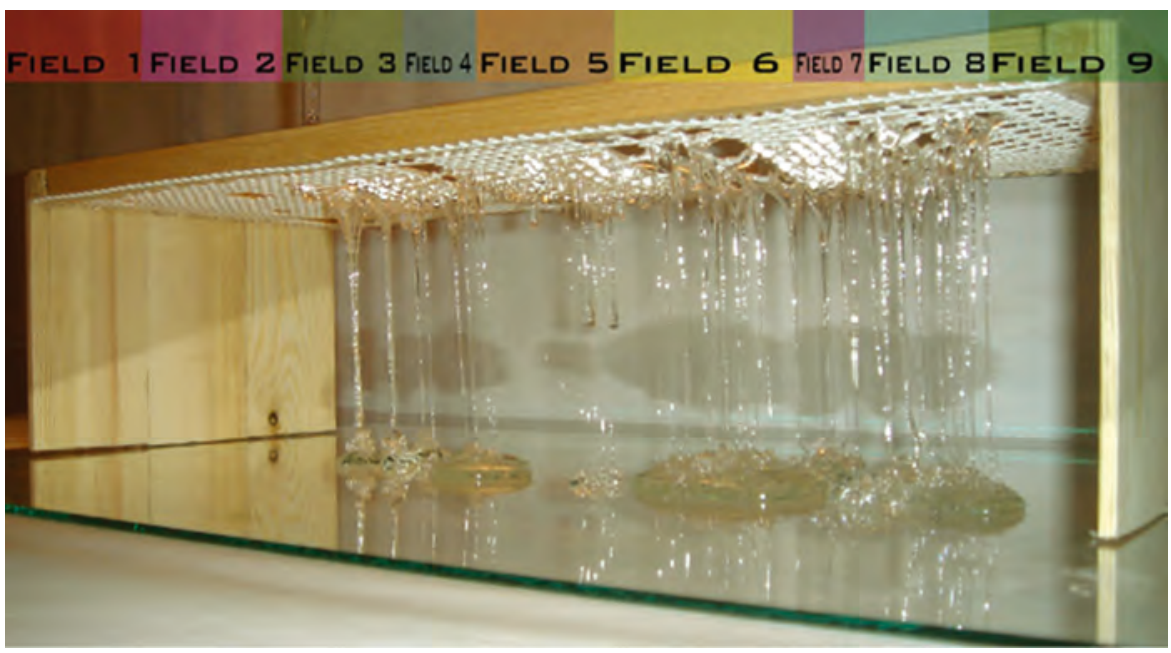

or non-intersecting sub-fields $\left(\mathrm{F}_{1}, \mathrm{~F}_{2}, \ldots \mathrm{F}_{9}\right)$ to create different levels and degrees of intricacy. The "Intricate Blob" project distributed itself into a sequence of 10, progressing from the smoothness or absence of detail of the perfect blob towards increasing levels of intricacy or cumulative detailing and striation. While the working medium was free, most students chose to realize the project within the physicality and richness of a material medium rather than simulating the forces involved on the computer (Figure 7a-d, 7e-f, 8a-c).

\section{CONCLUSION}

This studio experiment consisted of the design of some empirical settings to cover the new ground of formal complexity by experimenting with basic gestalt principles of perception. While it is beyond the scope of this design research to draw the limits of Gestalt theory or to offer an extension, it seems that this theory of perception is facing some challenges introduced by the complexity paradigm, though continuing to be a powerful theoretical source. The innate capacity for pattern recognition and the affiliated gestalt hypothesis of the minimizing tendency in perceptual processing expressed in the foundational law of prägnanz are seen to become problematic when the completion of a figure's gestalt is opposed by the openness or fuzziness of the whole. Such figures are counterintuitive and may overflow the human perceptual system. While the visual system may still strive to achieve minimizing tendencies, the minimum principle or the notion of perceptual economy leading to the simplest figure recognized can not be easily achieved. Deficiencies in human perception may explain why recent visual research shifts from psychology to the fields of visual and cognitive neurosciences, psychophysics, neurophysiology and neuroinformatics (King and Wertheimer, 2005, 385). The computational and cognitivist approaches of the neurosciences aim to augment the human perceptual apparatus with formal languages and quantitative procedures that simulate human response to supply for eventual perceptual deficiencies or failures in the organisation of complexity (9). However, the ever increasing complexity of the visual universe would require less a replacement than a sharpening and enhancement of human intuition if it is agreed that the enlargement and multiplicity of the formal template demands not only for a theory of perception but also for a theory of selection. The law of prägnanz in its double connotation provided 

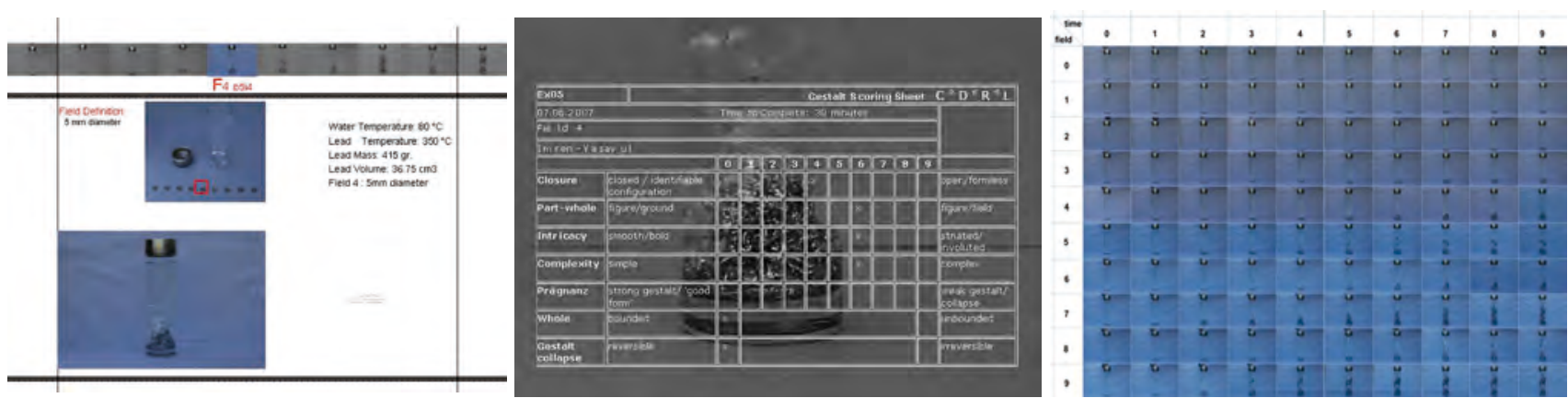

Figure 8a-c. Yasavul, M.S. and Imren, M.Z. (2007) Blob-Intricacy Scale. Test: Lead poured into water, $C^{\circ} D^{e} R^{e} L$. for such a theory of form selection in its assumption of the equivalence of the 'simplest' and the 'singular' or 'good' form, an assumption that in Bauhaus teaching grounded an aesthetic preference as well. The achievement of prägnanz is claimed to amount both to form recognition and to the fixity and singularity of this form recognized, hence acting as the versatile foundation of a theory of perception and an aesthetic theory. This ambiguity in the definition of prägnanz can be argued to become all the more questionable in the absence of an effective theoretical ground for perceptual and aesthetic preferences with regard to the increasing richness and variety of forms asking for improved visual processing.

\section{REFERENCES}

ARNHEIM, R. (1954, rev. 1974) Art and Visual Perception: A Psychology of the Creative Eye, University of California Press, Berkeley, California.

BEHRENS, R. (2004) Art, Design and Gestalt Theory, Leonardo On-Line.

Available from: http://www.leonardo.info/isast/articles/behrens.html [Accessed: 21 March 2006]

BOUTOT, A. (1993) L'invention des formes, Editions Odile Jacob, Paris

CACHE, B. (1999) Plea for Euclid, Any (24) 54-9.

CAMPEN, C. v. (1997) Early Abstract Art and Experimental Gestalt Psychology, Leonardo (30:2) 133-6.

CAMPEN, C. v. (1996) Picture Perception Research: Gibson's Continuation of the Gestalt and Bauhaus Tradition, 15th Cheiron Conference, Leiden, the Netherlands. Available from: http://www.synesthesie. nl/pub/cheiron.htm. [Accessed: 20 January 2009]

CARPO, M. (2004) Pattern Recognition, Focus, Vol. 3 of Metamorph, catalogue of the 9th International Biennale d'Architettura, Venice, ed. K. W. Forster, Marsilio and Rizzoli International, Venice and New York; 44-58.

CHRISTOPHER, A. (2002) The Nature of Order: An Essay on the Art of Building and the Nature of the Universe, Center for the Environmental Structure, Berkeley, California.

DENEL, B. (1979) A Method for Basic Design, Middle East Technical University, Faculty of Architecture Publication, Ankara.

DESOLNEUX, A., MOISAN, L. and MOREL, J-M. (2003) Computational Gestalts and Perception Thresholds, Journal of Physiology-Paris (97) 311-24. 
EPSTEIN, W. (1988) Has the Time Come to Rehabilitate Gestalt Theory? Psychological Research (50) 2-6.

EHRENFELS C. v. (1890/1988) On Gestalt Qualities, Foundations of Gestalt Theory, ed. and trans. B. Smith, Philosophia Verlag, Vienna; 82-117.

GÜNAY, B. (2007) Gestalt Theory and City Planning Education, METU Journal of the Faculty of Architecture (24:1) 93-113.

HATFIELD, G. and EPSTEIN, W. (1985) The Status of the Minimum Principle in the Theoretical Analysis of Visual Perception, Psychological Bulletin (97: 2) 155-186. Available from: http:/ / eprints. kfupm.edu.sa/71392/1/71392.pdf [Accessed: 25 May 2009]

KING, B., WERTHEIMER, M. (2005) Max Wertheimer and Gestalt Theory, Transaction Publishers, New Brunswick, New Jersey.

KOFFKA, K. (1935) Principles of Gestalt Psychology, Harcourt Brace, New York.

LYNN, G. (2003) Intricacy, ICA, University of Pennsylvania.

LUCCIO, R. (1999a) Self-Organization in Perception. The Case of Motion, Functional Models of Cognition, ed. A. Carsetti, the Netherlands, Kluwer Academic Publishers; 91-100.

LUCCIO, R. (1999b) On Prägnanz, Shapes of Forms: From Gestalt Psychology and Phenomenology to Ontology and Mathematics, ed. L. Albertazzi, the Netherlands, Kluwer Academic Publishers, 123-148.

LUCHINS, A.S. and LUCHINS, E.H. (1959) Comments on the Concept of Closure.

Extract from LUCHINS, A.S. and LUCHINS, E.H. (1959) Rigidity of Behavior - A Variational Approach to the Effect of Einstellung, University of Oregon Books, Eugene, Oregon; 273, 281f. Available from: http:// gestalttheory.net/archive/closure.html [Accessed: 15 March 2006]

LUPTON, E. (1991) Visual Dictionary, The ABC's of $\mathbf{\Delta} \mathbf{0}$ : The Bauhaus and Design Theory, eds. Lupton, E., Miller, A.J., Princeton Architectural Press; 22-33.

LUPTON, E, MILLER, A. J. eds. (1991) The ABC's of $\mathbf{A} \mathbf{0}$ : The Bauhaus and Design Theory, Princeton Architectural Press.

MASSUMI, B. (1995) Interface and Active Space: Human-Machine Design [online]. First published in the Proceedings of the Sixth International Symposium on Electronic Art (Montreal, 1995). Available from: http://www.anu.edu.au/HRC/first and last/works/interface.htm [Accessed: 8 march 2006]

MENNAN, Z. (2003) Des Formes Non Standard: Un 'Gestalt Switch', Architectures Non Standard, eds. F. Migayrou, Z. Mennan, Editions du Centre Pompidou, Paris; 34-41.

MENNAN, Z. (2006) Questioning Graphic Rationality in Architecture: Experimentations on the visual and the non-visual, paper presented at Architectural Education Forum 3: Global Architectural Education Area GAEA, Association for Architectural Education Arch-Ed, ITU, İstanbul, 15-17 November 2006.

MENNAN, Z. (2007) The Shifting Grounds of Gestalt Theory: A Problematization of Visual Perception within the Context of Self- 
Differentiating Forms, paper presented at Relations and Structures: Developments of Gestalt Theory in Psychology and Adjacent Fields, 15th Scientific Convention of the International Society for Gestalt Theory and its Applications, Macerata, Italy, 25-27 May 2007.

MOISAN, L. and MOREL, J-M. (2003) Computational Gestalts and Perception Thresholds, Journal of Physiology-Paris (97) 311-24.

SMITH, B. ed. (1988) Foundations of Gestalt Theory, Philosophia Verlag, Vienna.

SMITH, B. (1994) Austrian Philosophy : The Legacy of Franz Brentano, Open Court, Chicago and la Salle.

WERTHEIMER, M. (1911) Über das Denken der Naturvölker (On the Thinking of Indigenous People), Zeitschrift für Psychologie (60) 321-78.

WERTHEIMER, M. (1912) Experimentelle Studien über das Sehen von Bewegung (Experimental Studies of the Perception of Motion), Zeitschrift für Psychologie (61) 161-265.

WERTHEIMER, M. (1938) Laws of Organization in Perceptual Forms, A Source Book of Gestalt Psychology, ed. and trans. W. D. Ellis, Harcourt Brace, New York, 71-88. (First publication: (1923) Untersuchungen zur Lehre von der Gestalt II, Psycologische Forschung (4) 301-50. Available http: / / psy.ed.asu.edu/ classics / Wertheimer/Forms / forms.htm [Accessed: 25 February 2006]

WERTHEIMER, M. (1938) Gestalt Theory, A Source Book of Gestalt Psychology, ed. and trans. W. D. Ellis, Harcourt Brace, New York. (First publication: (1925) Über Gestalttheorie, an adress before the Kant Society, Berlin, 7th December 1924, Erlangen. Reprinted (1997) Gestalt Journal Press, New York.)

Alind1: 30.09.2009

Anahtar Sözcükler: Gestalt; alg1; prägnanz; kapanma; basitleştirme; karmaşıklık.

\section{BASITTEN KARMAŞIĞA: GESTALT ALGI KURAMI İLKELERINIIN KARMAŞIKLIK PARADİGMASI İÇINDE SÜRDÜRÜLEBİLİRLİĞİ}

Makale, 2006 ve 2007 Bahar dönemlerinde ODTÜ Mimarlık Bölümü'nde verilmiş bir yüksek lisans seçmeli stüdyosunun tasarım araştırmasını sunmaktadır. Bu tasarım araştırması, Gestalt kuramının görsel alg1 alanında geliştirmiş olduğu ilke ve kavramları karmaşıklık paradigmasının ürünü olan karmaşık ve kararsız biçimler bağlamında yeniden sorunsallaştırmayı amaçlamaktadır. Formel dil ve yöntemler karmaşık biçimlerin rasyonalizasyonunda giderek etkili olurken, bu biçimlerin algısal ve sezgisel kavranışındaki sorunlar da artmaktadır. Tasarım alanının güvenilir bir kaynağı olan Gestalt algı kuramının karmaşıklık paradigmasındaki kavramsal ve geometrik gelişmelerden ne olçüde etkilendiği ve bu gelişmelerin algı ve sezgi sistemlerine olan etkilerini araştırmak için tasarlanan, basitten karmaşığa uzanan temrinlerle yürütülen araştırmada, prägnanz, kapanma ve parça-bütün ilişkisi gibi niteliksel gestalt ilkeleri test edilmiştir.

Berlin ekolü tarafından geliştirilen Gestalt alg1 kuramının temel varsayımı olan, zihnin algılamada en basit, en kararlı ve en bütüncül düzeni seçtiği fikri, Wertheimer'in prägnanz yasasında dile getirilmiştir. Prägnanz hem 
bazı nesne veya biçimlerin sahip olduğu bir tekillik ve ayrıcalık (simetrik, düzgün biçimler bu tanıma girmektedir), hem de nesne veya biçimin algısal ekonomisi veya basitliği olarak tanımlanmaktadır. Prägnanz yasasını tartışmalı kılan da bu iki tanımın genellikle birbirine eşdeğer olarak kullanılması, başka bir deyişle, basit ve kararlı biçimlerin iyi gestaltlar olarak kabul edilmesidir. Örneğin Gestalt kuramını yakından izleyen Bauhaus eğitiminde basit ve soyut biçimlerin yeğlenmesi ile bir estetik stilin de altlığının oluşturulduğu söylenebilir.

Basitlik ve algısal ekonomi arayışı bütünün sezgisel olarak kavranabilirliği ile yakından ilişkilidir. Gestalt kuramında açıkça söylenmese de, burada sözü edilen bütünün 'sınırlı' ve 'kapalı' bir bütün olduğu düş̧ünülmektedir. Bu sav, kuramın parça-bütün ayrışması ve kontur çizgisi gibi öğelere verdiği önem ile de bağdaşmaktadır. Sınırlı bütün kavramı, gestalt ilkelerinin belli geometrilerde geçerli olduğunu işaret etmektedir. Buna dayanarak, daha önce metrik geometride test edilen aynı ilkeler, biçimi biçimsizlik sınırına getiren topolojik değişimler bağlamında yeniden test edilmiştir. Biçimin durağan ve kararlı olmasını engelleyen bu değişimlere örnek olarak 'blob' kavramı çalışılmış ve 'sınırlı bütün', kapanma ve prägnanz gibi ilkelerin blob gibi şekillerin tanımladığı ve bu araştırmada 'sınırsız bütün' olarak adlandırılan, kapanmanın sürekli olarak ertelendiği ve görsel imgenin bir bütün oluşturamadığı durumlarda sorunlu çalıştıkları gözlenmiştir. Görsel bütünün gözlemlenmesini ve algılanmasını zorlaştıran veya erteleyen bir karmaşıklık eşiği aşıldığında bütünün kendisini en basit durumda tutma eğilimi zorlanmaktadır.

Karmaşıklık karşısında insan algısındaki yetersizlikler, çağdaş görsel araştırmanın neden psikolojiden, neurobilimlerin sayısal ve bilişsel yaklaşımlarına kaydığını açıklamaktadır. Ancak, görsel dünyanın karmaşıklaşması, insan sezgi ve algısının yerine niceliksel modellerin konmasından çok, bu sistemlerin güçlendirilmesini gerektirmelidir çünkü biçimsel repertuarın genişlemesi, karmaşıklaşması ve zenginleşmesi yalnızca etkili bir algı kuramını değil, aynı zamanda bu biçimsel akışkanlığın ayıklanmasını sağlayabilecek bir estetik kuramını da gereksinmektedir. 